\title{
Risk society revisited: Challenging positions of COVID-19 on city and society
}

\author{
$*$ \\ Ezgi Orhan ${ }^{1}$ \\ ORCID: 0000-0002-9124-7812
}

\begin{abstract}
This paper presents a critical evaluation on the global riskscape following the COVID-19 pandemic. The coronavirus disease spread around the globe questioning the priorities in public health policies as well as the economic adaptability to prevention measures. Spreading with social, political and economic costs on societies, the issue of pandemic exceeds the limits of being identified as a health problem, and becomes to be a catalyst of a new paradigm considering the state of art of modernity and capitalist economic systems. Regarding the catastrophic impact on human life in all aspects, the virus-related problems lead individuals, nations and global society to evaluate the ways of 'living with risks'. Departing from the threat posed by the COVID-19, this paper discusses the issues of society, city and planning by reading the past experiences, current situation and trends through the concept of 'risk society'. It reflects on the historic dynamics of modernity, capitalism and public health priorities, and sheds light on the 'new normal' of the society at different scales for the post-pandemic world. Through the critical evaluation, this paper conceptualizes the new phase of risk society at individual, local, national and global scales; and portrays the dichotomies that each scale incorporates.
\end{abstract}

Keywords: risk society, critique of modernity, capitalism, city, planning.

\footnotetext{
${ }^{1}$ Assoc. Prof., Çankaya University, E-mail: ezgiorhan@cankaya.edu.tr idealkent @ Kent Araştırmaları Dergisi (Journal of Urban Studies) 


\title{
Risk toplumunu yeniden gözden geçirmek: COVID- 19'un kent ve toplum üzerindeki sorunlu halleri
}

\author{
Ezgi Orhan ${ }^{2}$ \\ ORCID: 0000-0002-9124-7812
}

\section{Öz}

Bu makale, COVID-19 salgının ardından küresel risk ortamının koşullarına ilişkin eleştirel bir değerlendirme sunmaktadır. Koronavirüs hastalı̆̆ı tüm dünyaya yayılırken halk să̆lığına dair öncelikler ile ekonomik uyum politikalarına dair alınan tedbirleri sorgulatmaktadır. Sosyal, politik ve ekonomik maliyetleriyle, toplumları zorluklara sürükleyen salgın konusu, bir sağllk sorunu olarak tanımlanmanın sınırlarını aşmıs ve modernite ve kapitalist ekonomik sisteme dair yeni bir paradigmanın katalizörü haline gelmiştir. Insan yaşamının her yönünde yarattığı ylkıcı etkileriyle, virüse ilişkin sorunlar bireyleri, ulusları ve küresel toplumu 'risklerle yaşama' yollarını düşünmeye yöneltmektedir. COVID-19'un ortaya koyduğu tehditten yola çıkan bu makale, geçmiş deneyimleri, mevcut durumu ve eğilimleri 'risk toplumu' kavramı üzerinden okuyarak, toplum, kent ve planlama ilişkilerini tartışmaktadır. Modernitenin, kapitalizmin ve halk sağglı̆̆ı önceliklerinin tarihsel dinamiklerini yansıtarak, salgın sonrası dünya için farklı ölçeklerde toplumun yeni normallerine ışık tutmaktadır. Eleştirel değerlendirme yoluyla, bu makale risk toplumunun yeni aşamaların bireysel, yerel, ulusal ve küresel ölçeklerde kavramsallaştırır ve her ölçeğin içerdiği ikilemi tasvir eder.

Anahtar Kelimeler: risk toplumu, modernite eleştirisi, kapitalizm, kent, planlama.

2 Doç. Dr., Çankaya Üniversitesi, E-mail: ezgiorhan@cankaya.edu.tr

idealkent @ Kent Araştırmaları Dergisi (Journal of Urban Studies)

http://idealkentdergisi.com

Geliş Tarihi Received Date: 14.02.2021 Kabul Tarihi Accepted Date: 26.08.2021 


\section{Introduction}

The birth of Enlightenment redefined the concept of 'risk', and gave a new perspective to individuals in conceiving the nature and demonstrating it in a rational way. However, the intense consequences of industrialization and capitalist economic system manifested themselves in a global circulation. The castles of medieval towns or borders of nation-states were melted in the heat of profitability ambition. Global circulation of capital not only turned the concrete boundaries into abstract lines, but also created a fictional sector shifting solid goods into financial flows (Harvey, 1978). The 'creative destruction processes' acted as a catalyst for causing an intense relation between human and nature, and making each one more vulnerable from the other (Schumpeter, 1950).

In this age of neo-liberal economic structure based on massive transitions, uneven agglomeration and harsh competitiveness, individuals and societies are vulnerable to the threats and risks that challenge their ability to intervene with their tools coming from scientific rationality. As a challenging position on human health, new coronavirus disease put societies in uncertain conditions and in an undetermined future by 'testing' their capacity to control the pandemic. Concomitantly, the industrialized societies facing with the disease are questioning the 'new equilibrium point' to reposition themselves for a further wave and an uncertain future. In this respect, the theoretical schema drawn by Ulrich Beck who advances the theory of 'risk society' is revisited in this paper (Beck, 1992). The paper aims to discuss the society, city and planning in the wake of a paradigmatic shift. To this end, the methodological framework is developed on a historical and critical read of the Beck's conceptualization. The contemporary risk society debate undertaken in the paper is constructed on the dichotomies that represent a categorical division of uncertainties identified at different scales. The uncertainties of society are presented through the dichotomies extracted for each scale that are categorized thus: global, national, local and individual levels. By this way, on the one hand, the issue of epidemics is examined in the risk society framework in chronologically, and on the other, the uncertainties posed by current pandemic are represented hierarchically to systematize the discussion.

This paper is organized around four parts. In the first part, the theoretical background of the discussion is structured around the concept of risk society. The second part presents the past experiences, current situation, and trends of modernity in face of epidemics. For portraying the post-pandemic world, the dichotomies of society are discussed at different levels that will be on the 
agenda of planning discipline. Consequently, the debate is reflected in the fourth part of the paper from the lens of uncertainty which would be the main assumption for further paradigms.

\section{Recalling the concept of risk society}

There emerged a diverse literature on 'risk society' concept in sociology, political ecology, political economy, and disaster studies as a critique to modernity. European social theorists claim that scientific rationality promoting economic progress is the cause of risks and vulnerability of society. According to the proponents, scientific progress and wealth accumulation processes put people at risk, and institutions become incapable of protecting people. The well-known researcher among these theorists is Ulrich Beck explains the motive of risk society as "social production of wealth is systematically accompanied by the social production of risks" (Beck, 1992, p. 19).

Risk society argument takes its roots from the critique of modernization and industrial society. In his epistemology, Beck notes that risk is not a new concept, but, in the contemporary world the difference comes from the "nature of risk". The modern industrial societies have been accepted to be capable of avoiding hazards, but they manufactured risks with the ends of technology, and hence technological changes bring new risks and problems whose nature would be influential at global level such as climate crisis, food security, and water supply. That is, the unintended consequences of modernity are distributed among society, and even, could turn into supra-national global threats. In this transformation, i.e. from industrial society to risk society, the formerly calculable risks shift into calculable threats (Beck, 1992). As the modernity freed itself from the contours of classical industrial society, it evolves to a new phase what Becks call as second modernity. In the second phase of modernity, risk society is shaped through the portrayal of "end of tradition" and "end of nature". Here, the risk society concept depicts an "un"ness condition; unreliability, unpredictability, uncontrollability, and uncertainty. The challenging position of post-modernity over instrumental rationality made the idea of controllability of future ineffective due to the intensification of five processes that are identified by Beck (1999) as globalization, individualization, gender revolution, underemployment, and global threats. These axes of capitalist growth contribute to the affluence-induced and poverty-induced environmental destruction, social fragmentation, and global financial risks. 
Risk societies are the outcomes of creative destruction of modernity, and inevitably manufactured within the industrial society. However, the ontological basis of individuals in risk society differs from the atomistic individual assumption of modern society. As an influential sociologist, Anthony Giddens claims that "there used to be the 'external risk' coming from the impact of nature on us; but we have added 'manufactured risks' due to our own impact on the world, for instance environmental risks or even social ones because our personal futures are increasingly open" (1998, p. 25). Individualization in risk society is highly related with the global conditions altering gender, family, class, parenthood, marriage, occupation structures as identified in a modern society (Beck, 1999; Dingwall, 1999). Additionally, individualization of social agent and flexibility of production system are forced to rethinking the new phase of industrial society. As a criticism to changing character of modernity and capitalist economic structure, Beck (1999) advocates that neoliberal economic policies promoted the interests of wealthy groups rather than protecting disadvantaged groups as well as public education and care. Facilitated in the organized irresponsibility, the limits of locally produced risks have turned into global, and global risks have been influential on localities that have not produced any risks. The "universaling tendency" of modernity, capitalism, and risks exceed the ability of coping solution, mechanisms, and instruments of single agencies, and are required to understand the unexpected, or in Beck's terms the unintended, consequences and emergencies in a wider perspective, and to evaluate in a multi-layered and multiactored rationality.

Challenging societies with their political, economic, and social costs, epidemics pose a threat on human life, and evoke uncertainty for global society. Next part, based on the concept of risk society, presents a discussion on how epidemics turn into disasters that disrupt the functioning of societies with a focus on modernity and capitalist system in a historical perspective.

\section{Epidemics: from disease to disaster}

\section{Pre-modern ages and risks}

Epidemics sourced by viruses began with the initial agricultural activity since the Neolithic period, around 12,000 years ago, when humans developed more densely populated agricultural communities. The shift from huntinggathering activities of humans to taming and domestication of animals, development in animal husbandry and farming activities allowed viruses to 
spread across communities rapidly. For Jared Diamond (1995) "diverse epidemic diseases of humans evolved in areas with many wild plant and animal species suitable for domestication, partly because the resulting crops and livestock helped feed dense societies in which epidemics could maintain themselves, and partly because the diseases evolved from germs of the domestic animals themselves" (1995, p. 87). As plant and animal domestication resulted in more food and surplus, human populations became denser and settled.

Gordon Childe pointed the thesis of first urban revolution as the mark of the progressive change in the economic and social structure of prehistoric communities that caused a dramatic increase in the population. In the hierarchy of evolutionary stages of prehistoric world, savagery and barbarism periods were dependent on hunting, collecting, fishing, and cultivating of eatable plant, that lead humans to live sparse in distance to extent their food derivation area (Childe, 1950; Diamond, 1995). In the civilization period coinciding the Neolithic Age, the number of persons living together was multiplied in a single settled area as a result of their efficient food derivation techniques, food transportation and storage. However, contrary to the members of savagery forms that camp and move to obtain food by leaving their microbes and bacteria behind, the civilized people began to live with their own sewage by settling. That is, while the nomadic life enables to exterminate the waste, the Neolithic villages and cities were contaminated by the civilized humans' residues. Since the agricultural production and urbanization of communities, the germs and bacteria have caused a variety of diseases and subsequently to become epidemic.

Epidemics were resulted in deaths before the rise of modern medicine. In the early mercantile world and antique period, the microbes were transmitted by trading activities. The trade routes of Roman period also carried the microbes between Asia, North Africa, and Europe, and "killed millions of Roman cities between A.D.165 and 180" (Diamond, 1995, p. 205). Respectively, Ancient Greeks and Romans constructed public baths to support personal hygiene and developed quarantine measures to avoid contagious. Medical historians and archaeologists claim that as a response to epidemics, quarantine was applied to provide isolation, correspond sanitary problems, and prevent illness in forms of limiting the entry or exit of travellers and sailors from the cities until distinguishing acute or contagious disease (Musto, 1986). In Medieval times, societies were not only limited by the surrounding castles but also myths, dogmas and divine rules that hampers and restricts scientific development. The cure for illnesses was a combination of superstition and 
natural healing. Magical and herbal remedies in addition to religious rituals were used in the treatment of diseases. Almost all sickness had unknown causes, but believed to be a punishment of God, therefore religious actions were accepted as the main motivation in the prevention and treatment of illness in medieval times. Respectively, human populations lived densely in the city-states with worse sanitation conditions. Thus, the fortified walls of selfsustaining and closed forms of medieval cities could not protect their communities from diseases and made them fragile for microbes. Therefore, the land trade with China and Europe, the Black Death epidemics killed millions around A.D. 1346. Similarly, oversea ventures contributed to the voyage of microbes and diseases. Columbus's arrival to America introduced the European germs and crowd diseases, infected and killed the Indian population, and hence, resulted in European colonialization of the New World. In addition to trading and discoveries, wars contributed to the transmission of diseases. To illustrate, 21 million people killed by influenza at the end of the World War I (Diamond, 1995). In brief, pre-modern ages set the most vulnerable environment for the epidemics in terms of both the ability of producing and generosity of disseminating it and incapability of treating illness.

\section{Modernity and risk construction}

Since the 18th century, the improvements in scientific calculations created a new way to understand the world and the future, which were previously under the control of divine forces. In the "age of reason", determinism and causalities explained the nature and represent it objectively (Hall and Gieben, 1992). The modern thinking gave humanity the tools of perceiving, understanding, assessing, judging and controlling nature (Orhan, 2015), and "protect themselves from its ravage" (Cohen, 1997, p. 107). The new world order enabled people to estimate the risks that they might face and take the control of events and decisions. The rational being could self-realize her/himself and accumulate to progress. The evolutionary dynamic of capitalism occurred in the sphere of industrial and commercial life was accompanied by social and institutional systems. Decline of traditional order and rise of modern states centralized the power by forming a constitutional, liberal, and democratic authority. The industrial bourgeoisie extended its sphere into political life to protect its economic interest against aristocracy with the Tiers-État which gained a political status in national assemble in 1789 marking the history of French Revolution. In addition, the modern bourgeois society "sprouted from 
the ruins of feudal society" (Marx and Engels, 1967, p.1) was simplified the class struggle, and divided the society as bourgeoisie and proletariat.

The closed structure of the feudal order was dissolved by manufacturing; eventually, the ever-rising demand and use of "steam and machinery revolutionized industrial production" (Marx and Engels, 1967). Development of industries since the end of the 18th century in England and Northern Europe gave rise to and changed urbanization trends. With the migration of rural population to industrial towns to incorporate the capitalist labour power, urban areas housed the proletariat with inadequate infrastructure, limited number of shelters, and crowding urban space. The principle of the 'right of work' that was blessed in capitalist system was criticised by Paul Lafargue as "mental aberration" in his book "The Right to be Lazy" (1880), and he claimed that modern factories became the prisons of men, women, and even children who were previously have their own houses in towns or villages (2012, p. 11). As the urban areas attracted rural population, new labour dwellings were intentionally constructed around factories. Polluting factors in addition to population increase and inadequate regulations led to the environmental, social and health problems in cities. Ecological deterioration in modern societies was seen "as a by-product of industrialization, but this is considered an unavoidable cost in the process of material acquisition" (Cohen, 1997, p. 111). Environmental pollution in air, soil, and water also acted a catalyst for low quality of life and diseases. Known as "crowd disease", epidemics of modernizing world began to spread over communities locating around the factories with inadequate technical infrastructure, lower life quality and causing lower averages in lifetime. In addition, wars triggered the dissemination of germs and war-borne microbes were victimized people who had no resistance to them. When the unexposed population encountered infected people and their diseases they carried, the transmitted disease devastated the populations until they developed immune.

As a solution to industrializing world problem, spatial planning was used as an instrument in guiding the public health and engineering the material wealth and progress by predicting and controlling future (Corburn, 2013). With the linear flow of time approach and with the widening space perception from the fortified towns of pre-modern world to nation-states in modernity, risks were both constructed widely and deeply, and eliminated by the means and instruments provided by modernity and its offspring, planning. To contribute to the well-being of nations, urban life was regulated, and planning was used to cheapen the urban services. Enlarging the medieval nuclei 
through the migration from rural to urban centres, the population began to live in congested and crowded quarters with narrow streets, limited vistas, multifamily residents, and mixed-used areas. The medieval fabric was characterized by organically formed streets and mixed-used areas where housing coexisted with artisanal workshops and small businesses, expanding outside the wall along the new roads from the hearth of the city towards rural spaces. Planning as an institution based on Enlightenment philosophy had a role in regulating the urban areas by defining the spatial organization of city. The elements of the initial urban planning approaches were the axial roads, geometrically designed buildings, gardens, symbolic and monumental structures, squares, and rationalization of land-use, as seen in the Baron GeorgesEugene Haussmann's Paris design during the Napoleon III's Empire (Waagenaar, 2010). Subsequently, the City Beautiful Movement became influential on the new world, and Daniel Burnham applied the approach in designing San Francisco, Chicago, Cleveland and Washington D.C in accomplishing the civic buildings, public spaces, parks and boulevards (Busa, 2010).

With the increasing control of man over nature which had connotations as of superstition, the enchanted world began to dissolve. Educated West awoke to a new sense of life, and took the power to stop epidemics, famine, early deaths, and devastating wars. Modernity progressed the scientific knowledge in three main domains, namely industry, agriculture, and medicine. In this respect, invention of machines and use of steel power eased the production; science ensured productive techniques to eliminate famine; and scientific knowledge reduced illness and treated diseases.

In this revolutionary economic system, risk was institutionalized as part of modern system. As the main motive of capitalism depended on accumulation, states provided and protected property rights contributing to the blossom out the belief in progress. Trust in a material progress either by individually or at aggregate level was harbingered by instrumentalist modernity, and eager capitalism. Despite its internal contradictions and crisis, capitalism usually "embodies a passionate drive for enlargement of profit" and accumulation (Elliot, 1980, p. 49). In this wavy journey of capitalism, state planning was seen a mediator in meeting the needs of people and overcoming the inherent crisis of capitalism. Particularly, following the overproduction crisis of capitalism, Keynesian welfare policies were internalized by states. Since the 1940s, governments introduced risk-sharing mechanisms for labour class (Orhan, 2015). Employment rights and social security policies were undertaken as the basis of welfare state. Particularly following the World War II, 
the state-provided benefits and regulation theory mechanized the wheels of capitalism by supporting social collective consumption. The unprecedented prosperity in capitalist western world together with catalysing technology of automobiles created the suburbs in the countryside, and city centres began to move away from cores and to radiate through low density residential areas (Jackson, 2011). However, the economic prosperity period and the swinging sixties, with full of freedom, hope and promise, was ended by the profitability crisis of capitalism.

\section{Post-modernity and reconceptualization of risk}

With the increasing costs of welfare policies on states' budget and low profitability of capitalists in addition to the drastic rise of oil prices led to the restructuration of the social, politic, and economic systems. On the one hand, states have initiated privatization policies and diminished their functions on public service provision. On the other hand, production process has been reorganized in a vertical mode allowing flexible, diverse, customized, and small amounts of production. The global circulation of capital and free movement of goods and people intensified trans-border relations and supported the post-Fordist mode of production. In addition to the continuing growth of capitalist mobility in worldwide, technological innovations condensed relations and elided spatial and temporal distances. The pre-modern spatial cognition which was depicted as experienced was shifted into an abstract one allowing people both to be in a fixed place and to flow in a virtual milieu. Rise of atypical employee contracts and post-Fordist mode of production transformed the spatial relations, and created a new flexible environment for businesses. The flexibility in capitalist mode of production bred disorganization and disorientation as well as decentralization. Also, economic internationalization decreased the share of manufacturing, and prompted the process of deindustrialization (Wyly et al, 1998). Such a dissolution process in cities led widely and adversely to uneven growth, income inequalities, poverty, international migration, social polarization, and high crime rates.

In the neo-liberal era of capitalism, the ontological basis of individuals has radically been changed, and identified at a new scale; he or she is a part of an order whose life is affected from distant others. Explaining the reason in the process of globalization, Mol and Spaargaren (1997, p.110) wrote that "highconsequence risks are risks which are remote from control by individual agents, while at the same time threatening the lives of millions of people and even humanity as a whole". While state control and insurance mechanisms 
are narrowing, individuals and societies are getting more fragmented, vulnerable, and segregated in economic, political, spatial, and social terms. As the production system and technological innovations provide more choice than ever, citizens become more individualized, and open to uncertainties, opportunities and risks in the absence of conventional politics and roots. In the open state of art of the world, the society has been trying "to correct environmental failings of contemporary production and consumption practices" through its instruments manufactured within the technological progress (Cohen, 1997, p. 106).

In this present globalized era, in a year-time, the coronavirus killed nearly 2.4 million victims, and remained as a threat to infect other members of the society. Observing more than 108 million confirmed cases, doctors and experts have not actually been able to forecast the course of the disease; the speed of the spread, further waves of the shock, variants of virus, getting immune, the ways of treat, and the help of vaccine on controlling the virus and its possible mutation forms.

During the first major wave of the pandemic, public health issues gained an urgent and firm position on the economic, political and social agenda all over the world. The highly virulent disease spread across the globe rapidly, and leave the entire world in living with uncertainties. The pandemic concretizes the identification of the new society concept of Giddens that refers to "a society where we increasingly live on a high-technological frontier which absolutely no one completely understands and which generates a diversity of possible futures" (1998, p. 25). As the individuals and communities departed from safe and calm waters of modernity and the institutional world, it is worthwhile to think and interpret again the risk society concept, and understand the uncertainties. In this respect, next part of the paper is devoted to conceptualize new normal options regarding the risk society at global, national, local and individual levels.

\section{Dichotomous options for the new normal of the interior society}

When Ulrich Beck calls "Second Modernity", the post-industrial and knowledge-based society is identified by being under the uncertainty regime. As the rate of knowledge production increased enormously and wealth accumulated intensely, the world society is subjected to "live with a calculative attitude to the open possibilities of action, positive and negative, with which, as individuals and globally, we are confronted in a continuous way in our 
contemporary social existence" (Giddens, 1991, p. 28). Departing from the case of COVID-19, the potential ways of 'living with risk' are critically evaluated from the planning perspective, and emerging dichotomous options are discussed at different levels.

\section{Global level}

Global scale, as the first unit of this present argument, stands as a dynamic spatial ontology as a result of the intensification of capitalist relations. Since the 1980s, nation-state boundaries have been evolving through the flowbased social and economic relations. The supra-territoriality of the globe is considered as the cause of the rapid virulent disease; therefore, one of the first initiatives of states would be the closure of the borders for people circulation. In the borderless stage of capitalism, the question on the new normality posed by pandemic produces a dichotomy on territories.

In this respect, states may demand to reorganize the production system to be self-sufficient in terms of basic goods and services. To provide food security and energy provision, states may create nationalized solutions and options in case of further limitations in export and import activities. Green economy and de-growth could be at the agenda of nations after experiencing the lockdown restrictions. Controversially, condensing economic activities and persistent capitalist relations could be firmed the transitional affiliations. In the post-pandemic period, economic recovery may require the strengthening of flows between countries to obtain a diverse labour, input and market range.

Governance in the post-pandemic world would be another significant issue to be discussed by starting from the global level under the dichotomy of territories. The new options could incorporate the diffusion of authority to sub-state and supra-national agencies. Development of governance could present channels for globalizing problems such as ecological and environmental degradation, enduring poverty and relentless inequalities. COVID-19 could be regarded as a catalyser for constructing solidarity around the globe. To illustrate, World Health Organization (2020) calls states to act together by arguing that "key tools in the coronavirus response must be made universally available as global public goods" in line with the principle of equity. In this tone, the acceptance of the fragility of the global system based on the shortterm gain oriented policies may lead states to construct an economic and international solidarity for a resilient future (Derviş, 2020). 


\section{National level}

In the process of globalization coinciding with COVID-19 pandemic, the positioning of nations across uncertainties seems to present a wide range of options. As authorities ordered confinement measures for protecting public health, the costs of these policies began to be paid immediately. While the benefits of protection are measured by lives saved, the costs that are difficult to estimate are reflected on the budgets of states, enterprises and individuals. Surveys addressing to economic repercussions of measures show that firms, particularly those operating in wholesale and retail trade, manufacture, real estate, business and administrative activities, accommodation and food services, transport, storage and communication, arts, entertainment and recreation sectors have been affecting at most (ILO, 2020), and at aggregate level, unemployment has been raising with a global expectation on economic recession (IMF, 2020). Under the circumstances of recessive global economic performance posed by pandemic, the feasibility of protection measures through welfare policies generates a dichotomy at national level.

Diminishing role of states among social classes of capitalism has reduced the protection power over working class and the guaranteed mechanisms between labour and capitalist, particularly since the 1980s. A poor majority of citizens "remain dependent on the provisions of a decaying welfare state" (Spaargaren, 1997, p. 197). However, the threat of the new coronavirus disease alarmed countries to act on behalf of protecting public health at the expense of stopping economic activities. When the pandemic changed its epicentre from China to Europe and then to Americas, the world witnessed the heavy consequences of weak public commitment in protective policies which serves to the spread of coronavirus to a large geography. The rapid sprawl of the disease urged states to provide welfare policies. While the confinement measures affected almost all economic sectors, many countries tightened the prevention measures to ensure public health. States, on the one hand, try to control the spread of the disease without hampering the operations of health services, and on the other, try to overcome the economic shrinkage by responding with financial aids. However, having repercussions on national economy, restrictive protection policies were required to be accompanied by fiscal aids to prevent economic instability. The bottleneck of the private enterprises and unemployment due to either decrease of consumption, reduction in purchasing power or business closure were aimed to be accomplished by state interventions. 
In this respect, for achieving the new equilibrium, state intervention and welfare policies are taken on the agenda. Public services could be synchronized by state, and social welfare could be achieved by state policies. Available supply of services and facilities to overcome the inequality and class differences among the society may be catered by authorities in a holistic manner. By this way, disadvantaged groups suffering from poverty may benefit from the state provision of goods and services. Such a particular prioritization in public health would enhance the well-being of citizen across risks. That is, public health issues need to be anchored and institutionalized into the frame of modernity although state provision of this service has been diminished since the eighties (Saunders, 1987). On the contrary, states may be forced to ease the prevention measures for disease to recover economic scars which have been seen as "weakened productivity, depressed investment, lost human capital, and shortened global supply chains" (World Bank, 2020).

\section{Local level}

As the physical proximity lost its significance due to the hypermobile characteristics of capital and technological innovation, the lockdown societies benefit from the remote services such as working, shopping, and learning. The blessings of a network society are largely appreciated in quarantine days by indoor citizens. However, when the isolations are loosened and lockdowns are ended, the questions on the new normal of daily routines of people come on the agenda. The conflictive position of the post-pandemic cities lies in the spheres of public and private.

A dominant private pattern could crush the publicness and public domain of the society. Citizens may ask for investments on private mode of consumption to ease their isolation or individualization processes. The most common forms of individual consumption are seen as the private automobile ownership, peripheral residential units, and private ownership of technological device which would result in the exploitation of urban areas through private interests. These individual demands may contribute to the protection of social distancing, as a prerequisite tool for controlling the spread of COVID-19. However, the redistribution of public policies in behalf of private demands inevitably lead to urban problems such as unregulated growth of city, uneven access to public services and common goods, privatization and commodification of space. Accepting the destructive side-effects of prioritization of private sphere on urban space, public policies may be designed for maintaining public health. Regarding that compact urban forms and high-density occupation of 
space may have effects on the spread of the disease; these spatial configurations may be preferred to ensure social mobility by walking and cycling. Also, selfsufficient neighbourhoods and/or sub-centres supported with mixed land-use and health-care facilities may be promoted by local authorities instead of the peripheral growth of the city.

\section{Individual level}

The capitalist assumption on atomistic individualism presupposes the enhancement of self-interest as the major motivation of modern consumer society. In the global order, the competitive structure of market has also reflections on the individual level. At the latest unit of the analysis, the positioning of individuals in the post-pandemic period presents a dichotomy in the domain of responsibility.

The COVID-19 posits in the Beck's risk society approach arguing that "the contemporary society and its subsystems are incapable of coping with their most urgent, self-generated problems" (Beck, 2009, p. 8). The coexistence of material growth and risks are generated within the global society through organized irresponsibility. On the way to achieve the new normal, individuals may ask more insurable domains, and thus institutionalized relations to reduce self-destruction of ever-growing material wealth. Such a path would generate a solid base for the construction of solidarity and public welfare. Contrarily, cosmopolitanism of individuals forced by the globalized capitalist relations may unavoidably lead to the internalization of uncertainties and global risks.

\section{Conclusion: The expense of interior society}

This paper contends that Beck's world risk society presents a dynamic conceptualization in explaining the contemporary conditions of the vulnerable social structure as an agglomeration of capitalist economic relations since the industrial revolution. The changing conjuncture of the globalization has changed the nature of risks. Forced by the coronavirus disease, world is now under pressure of developing a new approach to the new threat and is calibrating the conventional policies to overcome the uncertainty.

Despite waiting on the validation of the belief of "all risks were eventually routinized", (Dingwall, 1999, p. 8), in achieving the problems posed by the virus, a reflexive monitoring of actions is essential from individual to global levels. In this respect, this paper asserts that thinking in terms of risks is needed to be settled in public policies and individual responsibilities. 
Public policies are needed to be designed to avoid risks and their unintentional consequences. Basic security systems (Giddens, 1991) promoting a balance between risk and trust is essential to cope with the threats ranging from everyday life incidents to low probability catastrophes. These services should incorporate the protective policies on public health and economy without leaving citizens to make a choice over each other. Class struggles, gender and ethnicity segregations, and poverty leave nations and individuals unequal against the diseases. A world organized around economic ambitions and interests brings along with ecological and social risks. The potential of humanity's self-destruction emerged as a consequence of modernity in addition to wealth accumulation, should be regarded as the principal foci of concern. The affinity between wealth and risks is portrayed by Beck (1992, p. 36) as "hunger is hierarchical; smog is democratic". The case of COVID-19 affirms the claim of Beck since virus is democratic and deaths are hierarchical. In this respect, the systematically risk avoidance and risk reduction structure should be handled at global, national, local and individual levels. Negotiations between each level are required to avoid from the impacts of organized irresponsibility. The private domain of capitalist system and individual level actions are seen to be a part of public policy without allowing any contradiction between the public efforts and private ambitions.

Consequently, during the transition to a new world order, a reflexive thinking is required to alleviate the negative repercussions of intense progress. In this sense, all institutions of modernity including states, civic society and active citizens are supposed to be the parts of action and need to act for public interest and environmental concern. By this way, the Schumpeter's paradox of "capitalism is being destroyed because of its very creative success" (Elliot, 1980) could be achieved at global, national, local and individual levels.

\section{Kaynakça/References}

Beck, U. (1992). Risk society: On the way to an alternative modernity. Sage, Thousand Oaks Beck, U. (1999). World risk society. Polity Press, Cambridge.

Beck, U. (2009). Critical Theory of World Risk Society: A cosmopolitan vision, Constellations, 16(1):1-20.

Busa, A. (2010). City beautiful movement, in Hutchison, R. (Ed.) Encyclopaedia of Urban Studies. Sage Publications.

Childe, V. G. (1950). The urban revolution. Town Planning Review, 21(1), 3.

Cohen, M. J. (1997). Risk society and ecological modernization: Alternative visions for post-industrial nations, Futures, 29(2): 105-119. 
Corburn, J. (2013). Healthy city planning: From neighbourhood to national health equity, Routledge: Abingdon.

Derviş, K. (2020). The Covid-19 solidarity test, İstanbul Policy Centre, Analysis, April 2020.

Diamond, J. M. (1998). Guns, germs and steel: a short history of everybody for the last 13,000 years. Random House.

Dingwall, R. (1999). Risk society: The cult of theory and the Millennium?, Social Policy $\mathcal{E}$ Administration, 33(+): 474-491.

Elliott, J. E. (1980). Marx and Schumpeter on capitalism's creative destruction: A comparative restatement. The Quarterly Journal of Economics, 95(1), 45-68.

Giddens, A. (1991). Modernity and self-identity. Self and society in the late modern age. Cambridge: Polity Press.

Giddens, A. (1998). Risk society: the context of British politics. In: Franklin J (ed) The politics of risk society. Polity Press, Cambridge

Hall, S. and Gieben, B. (1992). Formations of modernity. Polity Press; The Open University.

Harvey, D. (1978). The urban process under capitalism: a framework for analysis. International Journal of Urban and Regional Research, 2(1-3), 101-131.

ILO (2020). ILO Monitor: COVID-19 and the world of work. Fourth edition, Updated estimates and analysis. International Labour Organization publications. May 27, 2020.

Jackson, K. T. (2011). The drive-in culture of contemporary America: From crabgrass frontier: The suburbanization of the United States (1985). In The City Reader (pp. 89-98). Routledge.

Lafargue, P. (2012). The right to be lazy. (Translated by C. Kerr), The Floating Press.

Marx, K. and Engels, F. (1967). The communist manifesto. 1848. (Translated by S. Moore). London: Penguin.

Mol, A. and Spaargaren, G. (1997). Environment, modernity and the risk-society; The apocalyptic horizon of environmental reform, in The ecological modernization of production and consumption; Essays in environmental sociology, Spaargaren, G. (ed.), Thesis Landbouw Universiteit Wageningen.

Musto, D. F. (1986). Quarantine and the problems of AIDS, The Milbank Quarterly, 97117.

Orhan, E. (2015). The consequences of security cognition in post-disaster urban planning practices in the case of Turkey, Natural Hazards, 76(1): 685-703.

Saunders, P. (1987). Social theory and the urban question. London: Unwin Hyman (2nd edition).

Schumpeter, J. A. (1950). Capitalism, socialism and democracy. New York: Harper.

Waagenaar, M. (2010). Haussmann, Baron Georges-Eugene, in Hutchison, R. (Ed.) Encyclopaedia of urban studies. Sage Publications. 
World Bank (2020). Lasting scars of the COVID-19 pandemic, retrieved from web page https:/www.worldbank.org/en/publication/global-economic-prospects, last accessed on June 03, 2020.

World Health Organization (2020). International community rallies to support open research and science to fight COVID-19, retrieved from web page https://www.who.int/news-room, last accessed on May 30, 2020.

Wyly, E. K., Glickman, N. J. and Lahr, M. L. (1998). A top 10 list of things to know about American cities. Cityscape, 7-32. 